\title{
BISPHENOL A DOSE- AND TIME-DEPENDENTLY INDUCES OXIDATIVE STRESS IN RAT LIVER MITOCHONDRIA EX VIVO
}

\author{
MOUSUMI DUTTA, GOUTAM PAUL*
}

Department of Physiology, Molecular Neurotoxicology Laboratory, University of Kalyani, Kalyani, Nadia - 741 235, West Bengal, India. Email: goutampaul.ku@gmail.com/gpaul@klyuniv.ac.in

Received: 17 April 2018, Revised and Accepted: 11 May 2018

\section{ABSTRACT}

Objective: The probable toxic effects of bisphenol A (BPA) on different physiological functions have been reported in animal models. The role of BPA in mitochondrial oxidative stress has not been reported till date. The present study is aimed to elucidate dose- and time-dependent oxidative stress generation by BPA, respectively, in rat liver mitochondria in ex vivo model.

Methods: The incubation mixture of BPA-treated groups containing mitochondria, $50 \mathrm{mM}$ potassium phosphate buffer (pH 7.4), and different concentrations of BPA (20-160 $\mathrm{MM} / \mathrm{ml}$ ) (dissolved in $12 \%$ DMSO) in a final volume of $1.0 \mathrm{ml}$ was incubated at $37^{\circ} \mathrm{C}$ in incubator for different time durations (30 min-2 h). Whereas, the incubation mixture of control group contained DMSO (12\%), mitochondria and 50 mM potassium phosphatebuffer (pH 7.4).' will be replaced by 'Whereas, the incubation mixture of control group contained the same constituents except BPA.

Result: We have observed significant decrease in mitochondrial intactness incubated with BPA in dose- and time-dependent manner under bright field and confocal microscopic study compared to control. Further, we have observed a decrease in mitochondrial reduced glutathione (GSH) content and increase in lipid peroxidation and protein carbonylation levels in dose- and time-dependent manner in BPA-exposed mitochondria. We have found a significant increase in the activity of Mn-superoxide dismutase and decrease in the activities of GSH peroxidase, GSH reductase, pyruvate dehydrogenase, and other three enzymes of Kreb's cycle dose and time dependently in BPA-exposed mitochondria. The results indicate that exposure to BPA leads to decrease in intactness of mitochondria and increase in oxidative stress in mitochondria isolated from rat liver in a dose- and timedependent manner.

Conclusion: It can be concluded that the incubation of mitochondria isolated from rat liver with BPA, caused oxidative stress-mediated damages in mitochondria in both dose- and time-dependent manners.

Keywords: Bisphenol A, Ex vivo model, Intactness of mitochondria, Kreb’s cycle enzymes, Mitochondria, Oxidative stress.

(C) 2018 The Authors. Published by Innovare Academic Sciences Pvt Ltd. This is an open access article under the CC BY license (http://creativecommons. org/licenses/by/4. 0/) DOI: http://dx.doi.org/10.22159/ajpcr.2018.v11i9.26750

\section{INTRODUCTION}

The lifestyle of the people has been rapidly changing due to scientific advancement and proliferation of consumerism in a global manner. It is not only restricted in urban areas but also in the rural areas. In this situation, majority of people in urban and rural areas are leaning toward the consumption of fast foods including the foods packaged in polycarbonate plastic containers or tin containers coated with epoxy resin at the interior are frequently fortified with bisphenol A (BPA). As a result due to weathering in many cases, BPA, the monomer of polycarbonate plastic and epoxy resin, and polymer of BPA are released to the foods, and when the people are exposed to the foods then the humans are also being exposed to the BPA.

BPA is a diphenylmethane derivative (Fig. 1a) which had been commercialized since 1957. BPA is also being used to form polycarbonate plastics through polymerization to make certain plastics and epoxy resins which are used to make a variety of common consumer goods, such as water bottles, sports equipment, compact discs, and digital versatile discs, line water pipes, as coatings on the inside of many food and beverage cans, and in making thermal paper, for example, sales receipts (Fig. 1b) [1]. In 2015, estimation indicated that 4 million tonnes of BPA chemical were produced for manufacturing polycarbonate plastics. The suitability of BPA in some consumer products and food containers raise a question because it shows estrogen-mimicking properties. The authorization of the use of BPA in baby bottles and infant formula packaging has been ended by the US Food and Drug Administration because its uses are not safe. Many bisphenol analogs exhibit endocrine disrupting effects, cytotoxicity, genotoxicity, reproductive toxicity, dioxin-like effects, and neurotoxicity in laboratory studies [2]. BPA causes autism in genetically susceptible children by inducing oxidative stress and mitochondrial dysfunction [3]. The motor functions of duodenal smooth muscle are also inhibited by BPA through induction of oxidative stress. These situations decrease the availability of free $\mathrm{Ca}^{2+}$, cause augmentation of the activity of acetylcholinesterase and promotion of the synthesis of nitric oxide (NO) in duodenal visceral smooth muscle [4,5]. Previous studies showed that in utero BPA exposure inhibits germ cell nest breakdown in the F1 generation of mice [6]. Earlier studies showed that BPA increased expression of HO-1 gene more than Gadd 45 gene at high doses. These genes are responsible for reactive oxygen species (ROS)dependent liver damages [7].

Mitochondria play an important role in the production of energy by operating tricarboxylic acid cycle and oxidative phosphorylation [8]. Besides, mitochondria profoundly participate in calcium homeostasis of cells involved in motor functions [9]. ROS are produced by singleelectron carriers in the respiratory chain of mitochondria which causes damage to the cell through lipid peroxidation (LPO), protein oxidation, and mitochondrial DNA (mtDNA) mutations. Apoptotic death of cell can be induced by oxidative stress and mitochondria play a central role in this process because it can release cytochrome c into the cytoplasm [10]. There is a possibility of the interaction of BPA in mitochondria-induced cellular apoptotic process. Mitochondria initiate the process of apoptosis by increasing its own oxidative stress and also the oxidative stress in the constituent cell. Therefore, the study of the 
oxidative stress in BPA-exposed mitochondria will give us an idea about the probable effects of BPA on cellular apoptosis also. Complexes I and III are also thought to be major sites for the production of superoxide and other ROS [11]. In addition, the mitochondrial respiratory chain is sensitive to nitration-mediated damages [12] which can modify the proteins of mitochondria. Protein oxidation and nitration result in altered functions of many metabolic enzymes in the mitochondrial electron-transport chain, including the nicotinamide adenine dinucleotide dehydrogenase, cytochrome c oxidase, and adenosine triphosphate synthase [13]. Hence, our present study has been carried out to test the causal relationship of BPA with hepatic mitochondrial oxidative stress. In our study, BPA produced oxidative stress, ex vivo, in mitochondria isolated from rat liver. BPA also showed the induction of oxidative stress, ex vivo, in rat liver mitochondria in a dose- and timedependent manner.

\section{METHODS}

\section{Chemicals and reagents}

All the chemicals used including the solvents were of analytical grade obtained from Sigma Chemicals Co. (USA), Sisco Research Laboratories, Mumbai, India, Merck Limited, Delhi, India.

\section{Animals}

Male Charles Foster rats, weighing 120-140 g, were obtained and were fed with standard diet and handled with care in Animal House as per the recommended guidelines of the Kalyani University Animal Ethics Committee.

\section{Animal sacrifice and collection of tissue samples}

The animals were sacrificed through cervical dislocation. The liver was removed surgically after carefully opening the abdominal cavity. The collected liver tissues were rinsed well in cold saline and soaked properly with a piece of blotting paper and stored in sterile vials at $-20^{\circ} \mathrm{C}$ for preparing mitochondria.

\section{Preparation of liver mitochondria}

Liver mitochondria were isolated according to the procedure of Dutta et al. [14] with some modifications. Two grams of tissue was placed in $10 \mathrm{ml}$ of sucrose buffer $(0.25[\mathrm{M}]$ sucrose, 0.001[M] EDTA, and 0.05[M] Tris- $\mathrm{HCl}\left[\mathrm{pH} \mathrm{7.8])}\right.$ at $25^{\circ} \mathrm{C}$. Then, the tissue was homogenized for $1 \mathrm{~min}$ at low speed using a Potter-Elvenjem glass homogenizer (Belco Glass Inc., Vineland, NJ, USA), after which it was centrifuged at $1500 \mathrm{rpm}$ for $10 \mathrm{~min}$ at $4^{\circ} \mathrm{C}$. The supernatant was then collected and kept in ice. Then, it was centrifuged at $4000 \mathrm{rpm}$ for $5 \mathrm{~min}$ at $4^{\circ} \mathrm{C}$. The supernatant, thus, obtained was further centrifuged at $14,000 \mathrm{rpm}$ for $20 \mathrm{~min}$ at $4^{\circ} \mathrm{C}$. The final supernatant obtained was discarded and the pellet was collected and resuspended in sucrose buffer and was stored at $-20^{\circ} \mathrm{C}$ for further assay.

\section{Incubation of mitochondria with BPA}

Initially, the mitochondria were divided into five groups. The incubation mixture of BPA-treated groups containing mitochondria (protein; $1.6 \mathrm{mg} / \mathrm{ml}$ ), $50 \mathrm{mM}$ potassium phosphate buffer ( $\mathrm{pH} 7.4$ ), and different concentrations of BPA (20-160 $\mu \mathrm{M} / \mathrm{ml}$ ) (dissolved in $12 \%$ DMSO) in a final volume of $1.0 \mathrm{ml}$ was incubated at $37^{\circ} \mathrm{C}$ in incubator for different time durations ( $30 \mathrm{~min}-2 \mathrm{~h}$ ). On the other hand, the incubation mixture of control group containing mitochondria (protein; $1.6 \mathrm{mg} / \mathrm{ml}$ ), 50 $\mathrm{mM}$ potassium phosphate buffer (pH 7.4), and DMSO (12\%) in a final volume of $1.0 \mathrm{ml}$ was incubated at $37^{\circ} \mathrm{C}$ in incubator for different time durations (30 min-2 h), also. The experimental design of dose- and time-kinetic study has been shown in Fig. 2. Following incubation, (a) the intactness of mitochondria; (b) reactive nitrogen species (RNS) generation; (c) the biomarkers of oxidative stress such as (i) the level of lipid peroxidation (LPO), (ii) the contents of reduced glutathione (GSH), and (iii) the level of protein carbonylation (PCO); and (d) the activities of (i) mitochondrial antioxidant enzymes, (ii) pyruvate dehydrogenase (PDH), and some of the Kreb's cycle enzymes, were determined as described below.

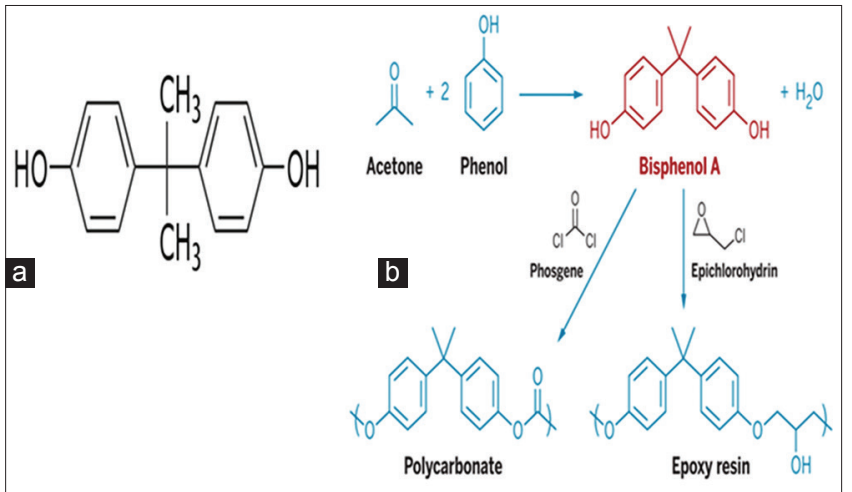

Fig. 1: (a) Chemical structure of bisphenol A (BPA), (b) Chemical transformation from BPA to polycarbonate and epoxy resin

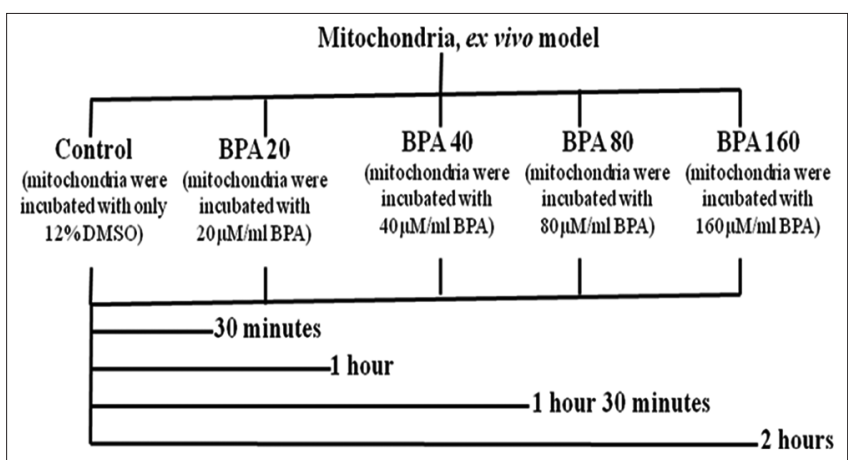

Fig. 2: Experimental design of dose- and time-kinetic study

Determination of mitochondrial intactness by using Janus green B stain

Following incubation, the mitochondria were spread on a slide. After that, a few drops of Janus green B stain were treated with the slide and were left for $5 \mathrm{~min}$ for staining in moist chamber. The mitochondria were rinsed once with distilled water so that the complete stain was not gone and a diluted stain remained. Then, the mitochondria were mounted in a drop of distilled water with a coverslip and imaged with bright-field microscope and a confocal system (BD Pathway 855, USA) [14].

\section{Measurement of the levels of RNS in mitochondria}

The concentrations of NO, one of the RNS in the incubated mitochondria, were measured spectrophotometrically at $548 \mathrm{~nm}$ according to the method of Fiddler, 1977, using Griess reagent $[15,16]$.

\section{Measurement of biomarkers of oxidative stress \\ LPO level}

The levels of LPO in the incubated mitochondria were determined according to the method of Buege et al. [17] with some modifications [18]. Briefly, the incubated mitochondria were mixed with thiobarbituric acid-trichloroacetic acid (TBA-TCA) reagent with thorough shaking and heated for $20 \mathrm{~min}$ at $80^{\circ} \mathrm{C}$. The samples were then cooled to room temperature. The absorbance of the orange chromogen present in the clear supernatant after centrifugation at $2000 \mathrm{rpm}$ for $10 \mathrm{~min}$ at room temperature was measured at $532 \mathrm{~nm}$ using a UV-VIS spectrophotometer. The unit was used as nmols of TBARS/mg protein.

\section{Reduced GSH content}

Reduced glutathione content was estimated by its reaction with DTNB (Ellman's reagent) following the method of Sedlak and Lindsay 1968. Incubated mitochondria were mixed with Tris- $\mathrm{HCl}$ buffer $(\mathrm{pH} 9.0)$, followed by DTNB for color development. The absorbance was measured at $412 \mathrm{~nm}$ to determine the GSH content. The values were expressed as nmole $\mathrm{GSH} / \mathrm{mg}$ protein [19]. 


\section{PCO level}

The level of PCO was estimated by the method of Levine et al., 1994 [20]. One-fourth of incubated mitochondria were taken in each tube and $0.5 \mathrm{ml}$ dinitrophenylhydrazine in $2 \mathrm{M}$ hydrochloric acid was added to the tubes. The tubes were vortexed every $10 \mathrm{~min}$ in the dark for $1 \mathrm{~h}$. Proteins were then precipitated with 30\% TCA and centrifuged at 10,000 rpm for $10 \mathrm{~min}$. The pellet was washed three times with $1 \mathrm{ml}$ of ethanol: ethyl acetate $(1: 1, \mathrm{v} / \mathrm{v})$. The final pellet was dissolved in $1 \mathrm{ml}$ of $6 \mathrm{M}$ guanidine-hydrochloride in $20 \mathrm{mM}$ potassium dihydrogen phosphate (pH 2.3). The absorbance was measured spectrophotometrically at $370 \mathrm{~nm}$. The values were expressed as $\mathrm{nmol} / \mathrm{mg}$ protein.

\section{Determination of the activities of antioxidant enzymes \\ Manganese superoxide dismutase (MnSOD) activity}

MnSOD activity was measured by pyrogallol autoxidation method [21]. To $50 \mu \mathrm{l}$ of the mitochondrial sample, $430 \mu \mathrm{l}$ of Tris-HCl buffer ( $50 \mathrm{mM}, \mathrm{pH}$ 8.2) and $20 \mu \mathrm{l}$ pyrogallol $(2 \mathrm{mM})$ were added. An increase in absorbance was recorded at $420 \mathrm{~nm}$ for $3 \mathrm{~min}$ in an ultraviolet (UV)-VIS spectrophotometer. The specific activity of the enzyme was expressed as units/mg protein.

\section{Glutathione reductase (GR) activity}

GR activity was determined according to the method of Krohne-Ehrich et al. [22] with some modifications [23]. Three-milliliter assay mixture contained $50 \mathrm{mM}$ phosphate buffer, $200 \mathrm{mM} \mathrm{KCl}$, and $1 \mathrm{mM}$ EDTA. The reaction was initiated with $1 \mathrm{mM}$ oxidized glutathione (GSSG). The decrease in NADPH absorption was monitored spectrophotometrically at $340 \mathrm{~nm}$. The specific activity of the enzyme was expressed as units/ mg protein.

\section{Glutathione peroxidase (GPX) activity}

GPx activity was measured according to the method of Paglia et al. [24], with some modifications as adopted by Dutta et al. [25]. The assay system contained $0.05 \mathrm{M}$ phosphate buffer with $2 \mathrm{mM}$ EDTA (pH 7.0), $0.025 \mathrm{mM}$ sodium azide, $0.15 \mathrm{mM} \mathrm{GSH}$, and $0.25 \mathrm{mM}$ NADPH along with suitable amount of mitochondria as the source of the enzyme (final volume of $1 \mathrm{ml}$ ). The reaction was started by the addition of $0.36 \mathrm{mM}$ $\mathrm{H}_{2} \mathrm{O}_{2}$. The linear decrease of absorbance at $340 \mathrm{~nm}$ was recorded using a UV-vis spectrophotometer. The specific activity of the enzyme was expressed as Units/mg protein.

\section{Determination of the activities of PDH and some of the Kreb's cycle enzymes}

\section{Pyruvate dehydrogenase (PDH) activity}

PDH activity was measured spectrophotometrically according to the method of Chretien et al., [26] by following the reduction of $\mathrm{NAD}^{+}$to $\mathrm{NADH}$ at $340 \mathrm{~nm}$ using $50 \mathrm{mM}$ phosphate buffer (pH 7.4), $0.5 \mathrm{mM}$ sodium pyruvate as the substrate and $0.5 \mathrm{mM} \mathrm{NAD}^{+}$in addition to the suitable amount of mitochondrial suspension (as the source of enzyme). The specific activity of the enzyme was expressed as units $/ \mathrm{mg}$ protein.

\section{Isocitrate dehydrogenase (ICDH) activity}

The activity of ICDH was measured according to the method of Duncan and Fraenkel [27] by measuring the reduction of $\mathrm{NAD}^{+}$to NADH at $340 \mathrm{~nm}$ with the help of a UV-vis spectrophotometer. One millimeter assay mixture contained $50 \mathrm{mM}$ phosphate buffer ( $\mathrm{pH}$ 7.4), $0.5 \mathrm{mM}$ isocitrate, $0.1 \mathrm{mM} \mathrm{MnSO}_{4}$, and $0.1 \mathrm{mM} \mathrm{NAD}^{+}$and the suitable amount of incubated mitochondrial suspension as the source of enzyme. The specific activity of the enzyme was expressed as Units/mg protein.

\section{Alpha-Ketoglutarate dehydrogenase ( $\alpha-K G D H)$ activity}

$\alpha$-KGDH activity was measured spectrophotometrically according to the method of Duncan and Fraenkel [27] by measuring the reduction of $\mathrm{NAD}^{+}(0.35 \mathrm{mM})$ to $\mathrm{NADH}$ at $340 \mathrm{~nm}$ using $50 \mathrm{mM}$ phosphate buffer (pH 7.4), $0.1 \mathrm{mM} \alpha$-ketoglutarate as the substrate and the suitable amount of incubated mitochondrial suspension as the source of enzyme. The specific activity of the enzyme was expressed as Units/mg protein.

\section{Succinate dehydrogenase (SDH) activity}

The activity of SDH was measured spectrophotometrically by following the reduction of potassium ferricyanide $\left[\mathrm{K}_{3} \mathrm{Fe}(\mathrm{CN})_{6}\right]$ at $420 \mathrm{~nm}$ according to the method of Veeger et al., [28] with some modifications [29]. One milliliter assay mixture contained $50 \mathrm{mM}$ phosphate buffer $(\mathrm{pH} 7.4)$, $2 \%(\mathrm{w} / \mathrm{v})$ bovine serum albumin, $4 \mathrm{mM}$ succinate, $2.5 \mathrm{mM}$ potassium ferricyanide $\left[\mathrm{K}_{3} \mathrm{Fe}(\mathrm{CN})_{6}\right]$, and the suitable amount of incubated mitochondrial suspension as the source of enzyme. The specific activity of the enzyme was expressed as Units/mg protein.

\section{Estimation of protein}

The protein content of the mitochondria from liver tissue was determined by the method of Lowry et al. [30].

\section{Statistical evaluation}

Each experiment was repeated at least six times. Data are presented as means \pm standard error. Significance of mean values of different parameters between the incubation mitochondria were analyzed using one-way post hoc tests (Tukey's HSD test) of analysis of variances after ascertaining the homogeneity of variances between the incubations. Pair-wise comparisons were done by calculating the least significance. Statistical tests were performed using Microcal Origin version 7.0 for Windows.

\section{RESULTS}

\section{Changes in intactness of mitochondria}

Fig. 3a-d depicts a significant decrease in the mitochondrial intactness following the incubation of mitochondria with BPA in a dose- and timedependent manner. It depicts a decrease in the mitochondrial intactness following the incubation of mitochondria with different doses $(20 \mu \mathrm{M} / \mathrm{ml}$, $40 \mu \mathrm{M} / \mathrm{ml}, 80 \mu \mathrm{M} / \mathrm{ml}$, and $160 \mu \mathrm{M} / \mathrm{ml}$ ) of BPA in a time-dependent manner. Fig. 3e reveals the intactness of mitochondria of various groups by the study with bright-field microscope (magnification $\times 40$ ).

\section{Changes in the level of NO of mitochondria}

The concentrations of NO in mitochondria in BPA-incubated groups $(20 \mu \mathrm{M} / \mathrm{ml}, 40 \mu \mathrm{M} / \mathrm{ml}, 80 \mu \mathrm{M} / \mathrm{ml}$, and $160 \mu \mathrm{M} / \mathrm{ml})$ were found to be increased significantly (Fig. 3f) when compared to the control group by $3.15 \%, 4.54 \%, 8.01 \%$, and $10.79 \%$ (in case of 30 min incubation) ( $\left.{ }^{*} \mathrm{p} \leq 0.001\right) ; 29.37 \%, 75.29 \%, 1.45$ folds, and 2.09 folds (in case of $1 \mathrm{~h}$ incubation) ( $\mathrm{p} \leq 0.001) ; 73.78 \%, 1.36$ folds, 2.94 folds, and 4.16 folds (in case of $1 \mathrm{~h} 30 \mathrm{~min}$ incubation) (^ $\mathrm{p} \leq 0.001$ ); and also $68.35 \%, 1.42$ folds, 3.15 folds, and 4.08 folds (in case of $2 \mathrm{~h}$ incubation) $\left({ }^{\circledR} \mathrm{p} \leq 0.001\right)$.

\section{Changes in the levels of LPO}

The levels of LPO in mitochondria in BPA-incubated groups $(20 \mu \mathrm{M} / \mathrm{ml}$, $40 \mu \mathrm{M} / \mathrm{ml}, 80 \mu \mathrm{M} / \mathrm{ml}$, and $160 \mu \mathrm{M} / \mathrm{ml}$ ) were found to be increased significantly (Fig. 4a) when compared to the control group by $4.77 \%$, $0.24 \%, 4.30 \%$, and $15.99 \%$ (in case of 30 min incubation) $\left({ }^{*} \mathrm{p} \leq 0.001\right.$ ); $30.88 \%, 49.64 \%, 76.48 \%$, and 1 fold (in case of $1 \mathrm{~h}$ incubation) ( $\left.{ }^{\#} \mathrm{p} \leq 0.001\right) ; 51.54 \%, 83.37 \%, 1.13$ folds, and 1.27 folds (in case of $1 \mathrm{~h}$ 30 min incubation) ( $\left.{ }^{\wedge} \mathrm{p} \leq 0.001\right)$; and also $46.35 \%, 82.35 \%, 1.03$ folds, and 1.21 folds (in case of $2 \mathrm{~h}$ incubation) $\left({ }^{\oplus} \mathrm{p} \leq 0.001\right)$.

\section{Changes in the contents of reduced GSH}

The contents of GSH in mitochondria in BPA-incubated groups $(20 \mu \mathrm{M} / \mathrm{ml}, 40 \mu \mathrm{M} / \mathrm{ml}, 80 \mu \mathrm{M} / \mathrm{ml}$, and $160 \mu \mathrm{M} / \mathrm{ml})$ were found to be decreased significantly (Fig. 4b) when compared to the control group by $2.79 \%, 7.14 \%, 8.89 \%$, and $14.74 \%$ (in case of 30 min incubation) $\left({ }^{*} \mathrm{p} \leq 0.001\right) ; 34.28 \%, 50.22 \%, 65.38 \%$, and $70.26 \%$ (in case of $1 \mathrm{~h}$ incubation) ( $\mathrm{p} \leq 0.001) ; 52.52 \%, 74.19 \%, 87.55 \%$, and $92.32 \%$ (in case of $1 \mathrm{~h} 30 \mathrm{~min}$ incubation) ( $\left.{ }^{\wedge} \mathrm{p} \leq 0.001\right)$; and also $54.52 \%, 81.23 \%$, $87.28 \%$ and $92.97 \%$ (in case of $2 \mathrm{~h}$ incubation) ( ${ }^{\circledR} \mathrm{p} \leq 0.001$ ).

\section{Changes in the levels of PCO}

The levels of PCO in mitochondria in BPA-incubated groups $(20 \mu \mathrm{M} / \mathrm{ml}$, $40 \mu \mathrm{M} / \mathrm{ml}, 80 \mu \mathrm{M} / \mathrm{ml}$, and $160 \mu \mathrm{M} / \mathrm{ml}$ ) were found to be increased significantly (Fig. 4c) when compared to the control group by $23.01 \%$, 


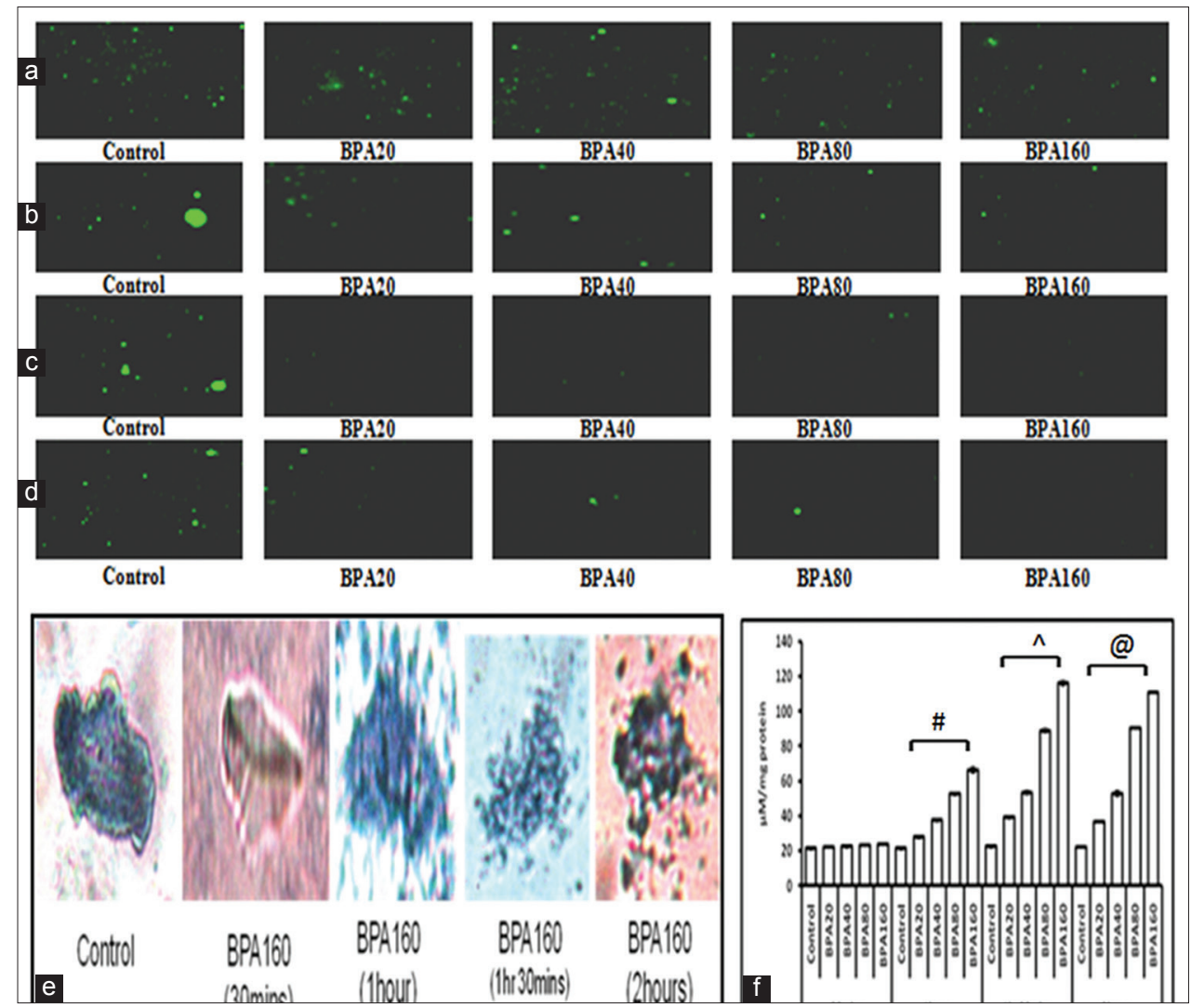

Fig. 3: Images representing bisphenol A (BPA)-incubated alterations in intactness ([a-d]: Janus green B stained [ $\times 40$ magnification]; [e] Bright-field microscopy [ $\times 40$ magnification]) and nitric oxide concentration [f] of mitochondria of control (30 min, $1 \mathrm{~h}, 1 \mathrm{~h} 30 \mathrm{~min}$, and 2 h) and BPA $(20 \mu \mathrm{M} / \mathrm{ml}, 40 \mu \mathrm{M} / \mathrm{ml}, 80 \mu \mathrm{M} / \mathrm{ml}$, and $160 \mu \mathrm{M} / \mathrm{ml}$ )-incubated groups (30 $\mathrm{min}, 1 \mathrm{~h}, 1 \mathrm{~h} 30 \mathrm{~min}$, and $2 \mathrm{~h})$ (" $\mathrm{p} \leq 0.001)$ (in case of $1 \mathrm{~h}$ incubation); ( $\mathrm{p} \mathbf{\mathrm { p }} \leq \mathbf{0 0 1}$ ) (in case of $1 \mathrm{~h} 30 \mathrm{~min}$ incubation); and ( ${ }^{\circledR} \mathrm{p} \leq 0.001$ ) (in case of $2 \mathrm{~h}$ incubation). Results have been expressed as mean \pm standard error of the mean

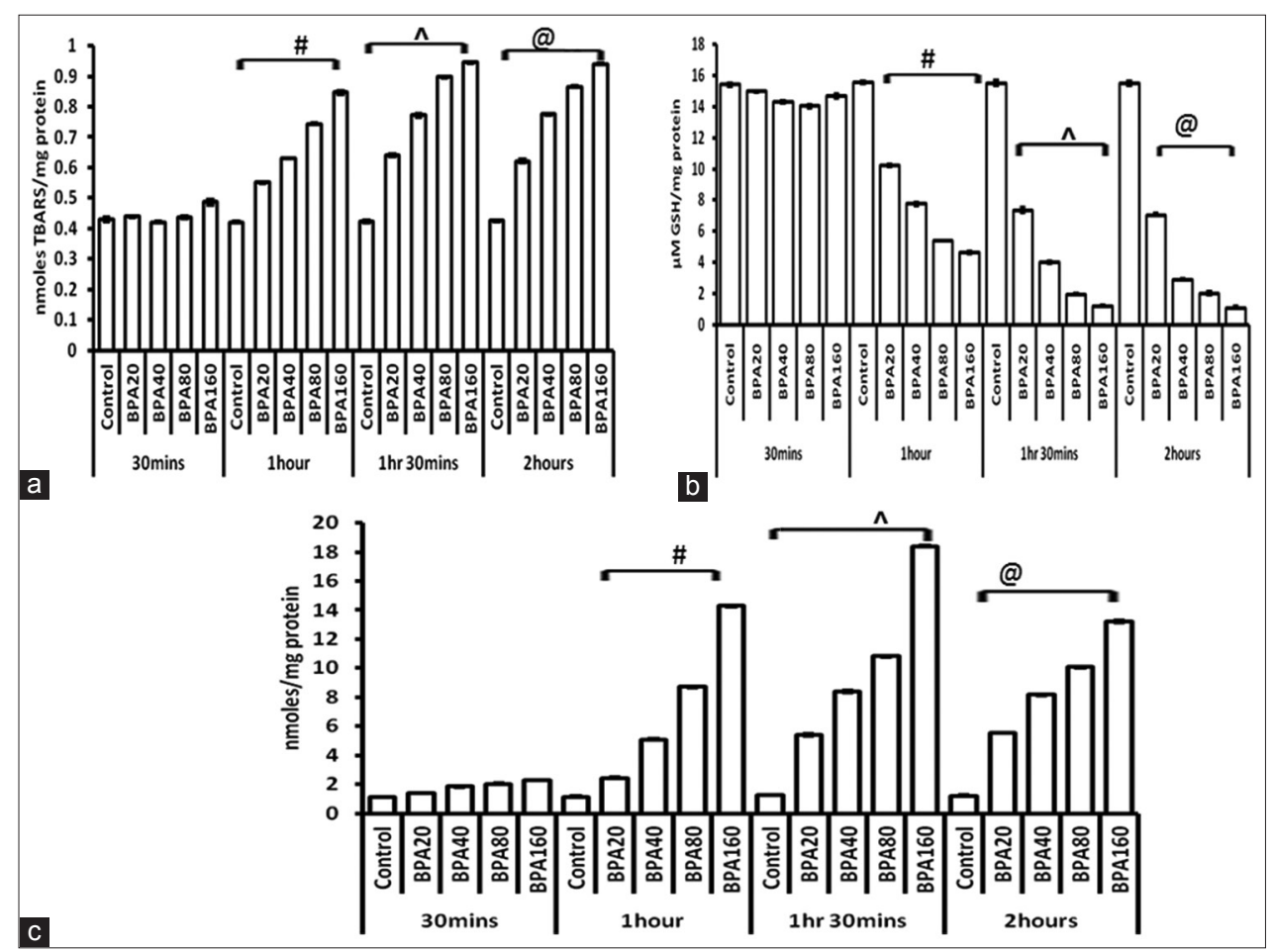

Fig. 4: Images representing bisphenol A (BPA)-incubated alterations in the content of reduced glutathione (a), levels of lipid peroxidation (b), and protein carbonylation (c) of mitochondria of control ( $30 \mathrm{~min}, 1 \mathrm{~h}, 1 \mathrm{~h} 30 \mathrm{~min}$, and $2 \mathrm{~h}$ ) and BPA (20 $\mu \mathrm{M} / \mathrm{ml}, 40 \mu \mathrm{M} / \mathrm{ml}, 80 \mu \mathrm{M} / \mathrm{ml}$, and $160 \mu \mathrm{M} / \mathrm{ml}$ )-incubated groups ( $30 \mathrm{~min}, 1 \mathrm{~h}, 1 \mathrm{~h} 30 \mathrm{~min}$ and $2 \mathrm{~h}$ ) ( $\left.{ }^{\#} \mathrm{p} \leq 0.001\right)$ (in case of $1 \mathrm{~h}$ incubation); ( $\left.{ }^{\wedge} \mathrm{p} \leq 0.001\right)$ (in case of $1 \mathrm{~h} 30$ min incubation); ( $\left.{ }^{\oplus} \mathrm{p} \leq 0.001\right)$ (in case of $2 \mathrm{~h}$ incubation). Results have been expressed as mean \pm standard error of the mean 
$63.72 \%, 80.53 \%$, and 1.03 folds (in case of 30 min incubation) $\left.{ }^{*} \mathrm{p} \leq 0.001\right) ; 1.13$ folds, 3.44 folds, 6.64 folds, and 11.6 folds (in case of $1 \mathrm{~h}$ incubation) ( $\left.{ }^{\#} \mathrm{p} \leq 0.001\right) ; 3.30$ folds, 5.65 folds, 7.57 folds, and 13.59 folds (in case of $1 \mathrm{~h} 30 \mathrm{~min}$ incubation) ( $\left.{ }^{\wedge} \mathrm{p} \leq 0.001\right)$; and also 3.65 folds, 5.87 folds, 7.42 folds, and 10.6 folds (in case of 2 h incubation) ( ${ }^{\circledR} \mathrm{p} \leq 0.001$ ).

\section{Changes in the activities of MnSOD}

The activities of MnSOD in mitochondria in BPA-incubated groups $(20 \mu \mathrm{M} / \mathrm{ml}, 40 \mu \mathrm{M} / \mathrm{ml}, 80 \mu \mathrm{M} / \mathrm{ml}$, and $160 \mu \mathrm{M} / \mathrm{ml}$ ) were found to be increased significantly (Fig. 5a) when compared to the control group by $6.76 \%, 9.18 \%, 2.09 \%$, and $0.97 \%$ (in case of $30 \mathrm{~min}$ incubation) ( $\left.{ }^{*} \mathrm{p} \leq 0.001\right) ; 69.41 \%, 1.78$ folds, 3.12 folds, and 5.67 folds (in case of $1 \mathrm{~h}$ incubation) (" $\mathrm{p} \leq 0.001$ ); 2.44 folds, 4.55 folds, 6.17 folds, and 10.83 folds (in case of $1 \mathrm{~h} 30 \mathrm{~m}$ incubation) ( $\left.{ }^{\wedge} \mathrm{p} \leq 0.001\right)$; and also 2.55 folds, 4.02 folds, 6.60 folds, and 11.29 folds (in case of 2 h incubation) $\left({ }^{\circledR} \mathrm{p} \leq 0.001\right)$.

\section{Changes in the activities of GPx}

The activities of GPx in mitochondria in BPA-incubated groups $(20 \mu \mathrm{M} / \mathrm{ml}, 40 \mu \mathrm{M} / \mathrm{ml}, 80 \mu \mathrm{M} / \mathrm{ml}$, and $160 \mu \mathrm{M} / \mathrm{ml}$ ) were found to be decreased significantly (Fig. 5b) when compared to the control group by $0.97 \%, 6.42 \%, 3.57 \%$, and $4.63 \%$ (in case of $30 \mathrm{~min}$ incubation) $\left({ }^{*} \mathrm{p} \leq 0.001\right) ; 33.43 \%, 51.51 \%, 71.08 \%$, and $85.48 \%$ (in case of $1 \mathrm{~h}$ incubation) ( $\left.{ }^{\#} \mathrm{p} \leq 0.001\right) ; 41.95 \%, 74.75 \%, 83.58 \%$, and $92.22 \%$ (in case of $1 \mathrm{~h} 30 \mathrm{~min}$ incubation) ( ${ }^{\wedge} \mathrm{p} \leq 0.001$ ); and also $41.25 \%, 77.02 \%$, $85.39 \%$, and $92.16 \%$ (in case of 2 h incubation) $\left({ }^{@} \mathrm{p} \leq 0.001\right)$.

\section{Changes in the activities of GR}

The activities of GR in mitochondria in BPA-incubated groups (20 $\mu \mathrm{M} / \mathrm{ml}, 40 \mu \mathrm{M} / \mathrm{ml}, 80 \mu \mathrm{M} / \mathrm{ml}$, and $160 \mu \mathrm{M} / \mathrm{ml}$ ) were found to be decreased significantly (Fig. 5c) when compared to the control group by $4.43 \%, 11.98 \%, 14.32 \%$, and $17.45 \%$ (in case of $30 \mathrm{~min}$ incubation) $\left({ }^{*} \mathrm{p} \leq 0.001\right) ; 37.57 \%, 52.43 \%, 62.43 \%$, and $79.19 \%$ (in case of $1 \mathrm{~h}$ incubation) ( $\left.{ }^{\mathrm{p}} \leq 0.001\right) ; 43.25 \%, 61.00 \%, 81.50 \%$, and $87.50 \%$ (in case of 1 h $30 \mathrm{~min}$ incubation) ( ${ }^{\wedge} \mathrm{p} \leq 0.001$ ); and also $45.40 \%, 65.63 \%$, $78.65 \%$, and $88.02 \%$ (in case of $2 \mathrm{~h}$ incubation) $\left({ }^{@} \mathrm{p} \leq 0.001\right.$ ).
Changes in the activities of PDH

The activities of $\mathrm{PDH}$ in mitochondria in BPA-incubated groups $(20 \mu \mathrm{M} / \mathrm{ml}, 40 \mu \mathrm{M} / \mathrm{ml}, 80 \mu \mathrm{M} / \mathrm{ml}$, and $160 \mu \mathrm{M} / \mathrm{ml})$ were found to be decreased significantly (Fig. 6a) when compared to the control group by $3.95 \%, 12.66 \%, 17.29 \%$, and $12.85 \%$ (in case of $30 \mathrm{~min}$ incubation) $\left({ }^{*} \mathrm{p} \leq 0.001\right) ; 27.50 \%, 47.39 \%, 61.64 \%$, and $72.37 \%$ (in case of $1 \mathrm{~h}$ incubation) ( $\left.{ }^{\#} \mathrm{p} \leq 0.001\right) ; 43.82 \%, 55.09 \%, 67.32 \%$, and $80.29 \%$ (in case of $1 \mathrm{~h} 30 \mathrm{~min}$ incubation) ( ${ }^{\wedge} \mathrm{p} \leq 0.001$ ); and also $46.68 \%, 57.73 \%, 67.67 \%$, and $78.44 \%$ (in case of $2 \mathrm{~h}$ incubation) (@ $\mathrm{p} \leq 0.001)$

\section{Changes in the activities of ICDH}

The activities of ICDH in mitochondria in BPA-incubated groups $(20 \mu \mathrm{M} / \mathrm{ml}, 40 \mu \mathrm{M} / \mathrm{ml}, 80 \mu \mathrm{M} / \mathrm{ml}$, and $160 \mu \mathrm{M} / \mathrm{ml})$ were found to be decreased significantly (Fig. 6b) when compared to the control group by $24.80 \%, 59.06 \%, 66.34 \%$, and $85.04 \%$ (in case of $1 \mathrm{~h}$ incubation) $\left({ }^{\#} \mathrm{p} \leq 0.001\right) ; 55.41 \%, 74.52 \%, 83.78 \%$, and $90.15 \%$ (in case of $1 \mathrm{~h}$ 30 min incubation) ( $\left.{ }^{\wedge} \mathrm{p} \leq 0.001\right)$; and also $57.17 \%, 72.66 \%, 83.37 \%$, and $90.63 \%$ (in case of $2 \mathrm{~h}$ incubation) ( $\left.{ }^{\circledR} \mathrm{p} \leq 0.001\right)$.

\section{Changes in the activities of $\alpha$-KGDH}

The activities of $\alpha$-KGDH in mitochondria in BPA-incubated groups $(20 \mu \mathrm{M} / \mathrm{ml}, 40 \mu \mathrm{M} / \mathrm{ml}, 80 \mu \mathrm{M} / \mathrm{ml}$, and $160 \mu \mathrm{M} / \mathrm{ml})$ were found to be decreased significantly (Fig. 6c) when compared to the control group by $1.01 \%, 8.97 \%, 0.82 \%$, and $5.12 \%$ (in case of $30 \mathrm{~min}$ incubation) $\left.{ }^{*} \mathrm{p} \leq 0.001\right) ; 25.88 \%, 45.23 \%, 69.12 \%$, and $80.15 \%$ (in case of $1 \mathrm{~h}$ incubation) ( $\left.{ }^{\#} \mathrm{p} \leq 0.001\right) ; 39.39 \%, 55.18 \%, 67.79 \%$, and $76.87 \%$ (in case of $1 \mathrm{~h} 30 \mathrm{~min}$ incubation) ( ${ }^{\wedge} \mathrm{p} \leq 0.001$ ); and also $27.09 \%, 49.70 \%$, $65.08 \%$, and $75.18 \%$ (in case of 2 h incubation) $\left({ }^{@} \mathrm{p} \leq 0.001\right)$.

\section{Changes in the activities of SDH}

The activities of SDH in mitochondria in BPA-incubated groups $(20 \mu \mathrm{M} / \mathrm{ml}, 40 \mu \mathrm{M} / \mathrm{ml}, 80 \mu \mathrm{M} / \mathrm{ml}$ and $160 \mu \mathrm{M} / \mathrm{ml}$ ) were found to be decreased significantly (Fig. 6d) when compared to the control group by $3.51 \%, 3.36 \%, 2.60 \%$, and $7.18 \%$ (in case of $30 \mathrm{~min}$ incubation) $(* \mathrm{p} \leq 0.001) ; 16.67 \%, 59.40 \%, 74.59 \%$, and $84.03 \%$ (in

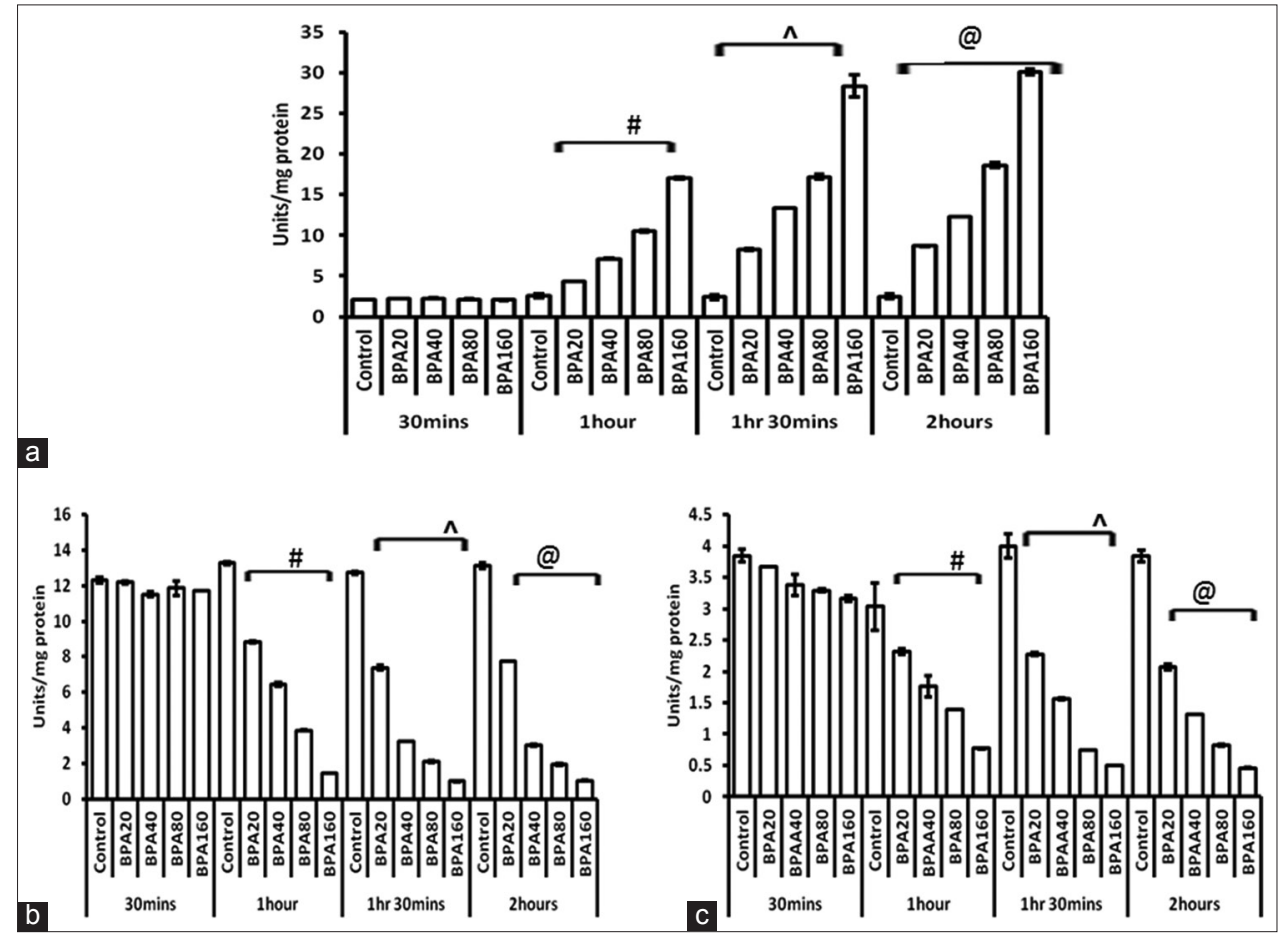

Fig. 5: Images representing bisphenol A (BPA)-incubated alterations in the activities of Mn-superoxide dismutase (A), glutathione peroxidase (B) and glutathione reductase (C) of mitochondria of control (30 min, $1 \mathrm{~h}, 1 \mathrm{~h} 30 \mathrm{~min}$, and $2 \mathrm{~h}$ ) and BPA (20 $\mu \mathrm{M} / \mathrm{ml}, 40 \mu \mathrm{M} / \mathrm{ml}$, $80 \mu \mathrm{M} / \mathrm{ml}$, and $160 \mu \mathrm{M} / \mathrm{ml}$ )-incubated groups ( $30 \mathrm{~min}, 1 \mathrm{~h}, 1 \mathrm{~h} 30 \mathrm{~min}$, and $2 \mathrm{~h}$ ) ( $" \mathrm{p} \leq 0.001)$ (in case of $1 \mathrm{~h}$ incubation); ( $\left.{ }^{\wedge} \mathrm{p} \leq 0.001\right)$ (in case of $1 \mathrm{~h} 30 \mathrm{~min}$ incubation); and ( ${ }^{\circledR} \mathrm{p} \leq 0.001$ ) (in case of $2 \mathrm{~h}$ incubation). Results have been expressed as mean \pm standard error of the mean 

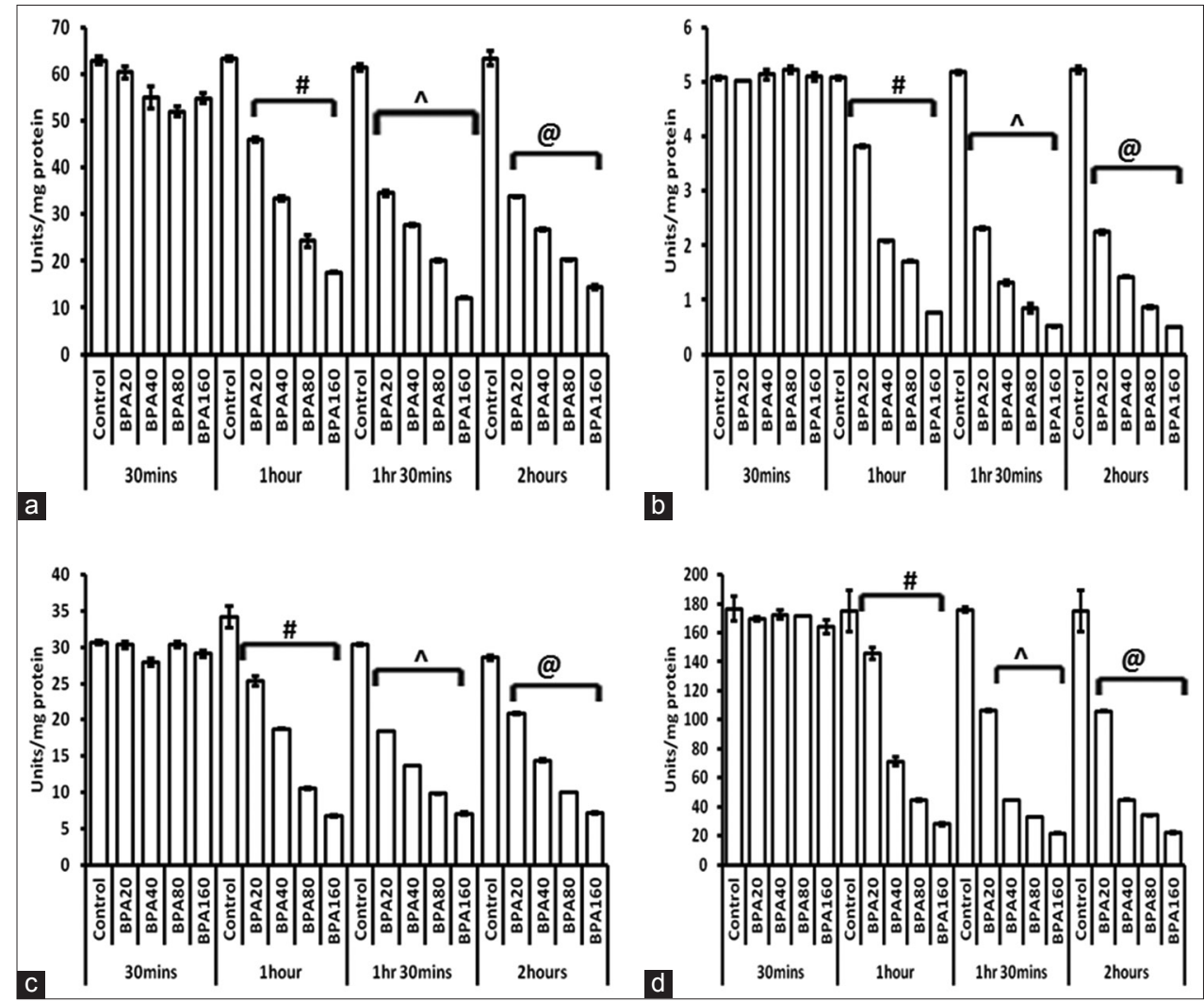

Fig. 6: Images representing bisphenol A (BPA)-incubated decreases in the activities of pyruvate dehydrogenase (a), isocitrate dehydrogenase (b), $\alpha$-ketoglutarate dehydrogenase (c) and succinate dehydrogenase (d) of mitochondria of control ( $30 \mathrm{~min}, 1 \mathrm{~h}, 1 \mathrm{~h} 30$ min, and $2 \mathrm{~h})$ and BPA $(20 \mu \mathrm{M} / \mathrm{ml}, 40 \mu \mathrm{M} / \mathrm{ml}, 80 \mu \mathrm{M} / \mathrm{ml}$, and $160 \mu \mathrm{M} / \mathrm{ml})$-incubated groups (30 min, $1 \mathrm{~h}, 1 \mathrm{~h} 30 \mathrm{~min}$, and $2 \mathrm{~h})\left({ }^{\#} \mathrm{p} \leq 0.001\right)$

(in case of $1 \mathrm{~h}$ incubation); ( ${ }^{\wedge} \mathrm{p} \leq 0.001$ ) (in case of $1 \mathrm{~h} 30 \mathrm{~min}$ incubation); ( $\left.{ }^{\circledR} \mathrm{p} \leq 0.001\right)$ (in case of $2 \mathrm{~h}$ incubation). Results have been expressed as mean \pm standard error of the mean

case of $1 \mathrm{~h}$ incubation) ( $\left.{ }^{\mathrm{p}} \mathrm{p} \leq 0.001\right) ; 39.43 \%, 74.76 \%, 81.33 \%$, and $87.67 \%$ (in case of $1 \mathrm{~h} 30 \mathrm{~min}$ incubation) (^p $\leq 0.001$ ); and also $39.47 \%, 74.43 \%, 80.50 \%$, and $87.35 \%$ (in case of $2 \mathrm{~h}$ incubation) $\left({ }^{\circledR} \mathrm{p} \leq 0.001\right)$

\section{DISCUSSION}

Mitochondria are the main source of generation of the superoxide anion free radical $\left(\mathrm{O}_{2} \cdot\right)$ and other ROS [31]. The main mechanisms responsible for mitochondrial ROS production are the oxidative phosphorylation which occurs in the respiratory chain, in particular, its complexes I and III [32], in the inner mitochondrial membrane, and monoamine oxidase in the outer membrane. The noxious action of ROS mainly consists of the peroxidation of lipids, in particular, phospholipids of biological membranes and oxidative damage to proteins and DNA [33]. BPA can leach into food from the epoxy resin lining of cans and from consumer products such as polycarbonate tableware, food storage containers, water bottles, and baby bottles. Additional traces of BPA can leach out of these products when they are heated at high temperatures. Recent studies have also suggested that people may be exposed to BPA by handling cash register receipts which are made up of components containing BPA as one of the constituents.

When the human body is being exposed to BPA (itself contains strong electron donating group $(-\mathrm{OH})$ in its structure) then it will be biotransformed in the liver and gut by glucuronosyltransferases and SULTs, respectively, to BPA glucuronide containing strong electron donating group $(-\mathrm{OH})$ in its structure which can donate electrons to the free oxygen to produce superoxide free anion radical $\left(\mathrm{O}_{2}^{-}\right)$, which is one of the causative factors of oxidative stress in the physiological system. It has been shown that the BPA by decreasing expression of the gene responsible for prevention of oxidative activity can induce production of ROS and subsequent hepatotoxicity as well [34]. NO is a free radical which plays an important role in the pathogenesis of pain, inflammation, neural signal transmission, immune response, control of vasodilatation, and blood pressure [35,36]

GSH provides the first line of defense against ROS, as it can scavenge free radicals and reduce $\mathrm{H}_{2} \mathrm{O}_{2}$ BPA can produce various quinol and semiquinone intermediates which can react with GSH to produce GSH conjugates which are responsible for the generation of oxidative stress. LPO levels are assayed to determine the extent of oxidative damages involving mainly membrane lipids. Free radicals produced due to oxidative stress can easily react with lipids of the cell membrane and thereby initiating a chain reaction leading to the production of lipid peroxides [37]. On the other hand, PCO levels are estimated to study the protein oxidations owing to their early formation and higher stability.

The cellular antioxidant system against oxidative stress comprises the tripeptide GSH and few enzymes regulating its metabolism. GPx uses reduced GSH to remove peroxides produced due to oxidative stress. On the other hand, GR reduces the oxidized GSH back to GSH using NADPH [38].

PDH has been demonstrated to be sensitive which induce oxygen free radicals, which might be a cause of decrease of the enzyme activity [39]. ICDH is a major NADPH producer in the mitochondrial Kreb's cycle pathway and thus plays a key role in cellular defense against oxidative stress-induced damage. During marked elevation in ROS generation, DNAfragmentation and a decrease in the activity of ICDH were observed [40].

A study by Chitra et al., 2003, on epididymal sperm of rats due to BPAinduced oxidative stress had shown that graded dose of BPA elicits the depletion of antioxidant defense system and responsible for oxidative stress generation in epididymal sperm of rats which corresponds to our results on graded incremental dose of BPA induces oxidative 


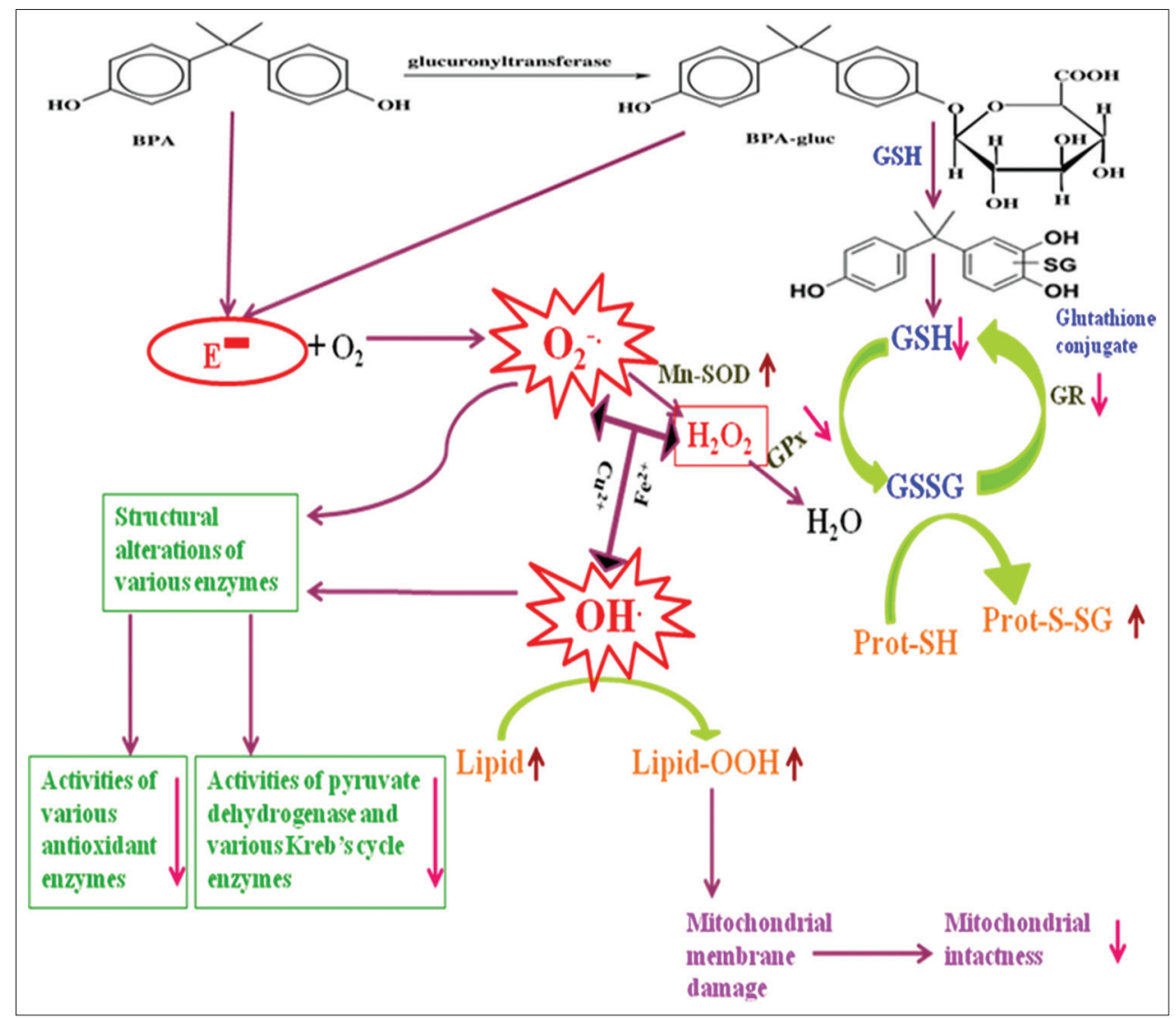

Fig. 7: Scheme showing the probable mechanism of generation of oxidative stress by BPA in hepatic mitochondria

stress in ex vivo liver mitochondrial model [41]. A research study by Moon et al., 2012, had shown that BPA doses below the NOAEL (noobserved-adverse-effect level) can induce mitochondrial dysfunction in the liver which is associated with an increase in oxidative stress and inflammation. Our experimental results had shown that graded micromole $(\mu \mathrm{M})$ concentrations of BPA induced similar effects in mitochondrial ex vivo model [42]. GSH depletion could lead to an oxidative stress condition which is being supported by the presence of increased levels of MDA concentration in the GSH-depleted mitochondrial system. This statement has also been supported by the present study and also by an earlier study [43].

In our study, the intactness of mitochondrial structure, concentrations of NO, levels of LPO and PCO, contents of GSH and activities of various antioxidant enzymes (Mn-SOD, GPx, GR), and also activities of PDH and various Kreb's cycle enzymes (ICDH, $\alpha$-KGDH, SDH) were found to be altered significantly in all the BPA-incubated groups $(20 \mu \mathrm{M} / \mathrm{ml}, 40 \mu \mathrm{M} / \mathrm{ml}, 80 \mu \mathrm{M} / \mathrm{ml}$, and $160 \mu \mathrm{M} / \mathrm{ml})$ as compared to the control group at all the time points studied. The probable mechanism of generation of oxidative stress by BPA is that the BPA can react with reduced GSH and produce GSH conjugate which is responsible for decreasing content of reduced GSH and this reaction may be responsible for alteration of GSH/GSSG ratio. Another mechanism of generation of oxidative stress by BPA is that BPA can generate higher concentration of electron may be by altering the respiratory chain reactions which can produce higher amount of superoxide free radicals. This free radical itself and also by producing hydroxyl radical causes oxidative stress. As a result of BPA-induced oxidative stress, the enzymes of tricarboxylic acid cycle and mitochondrial electron transport chain might be altered. Consequently, ATP synthesis by the mitochondrial respiratory chain of the BPA-exposed mitochondria might be inhibited; and, thus, ATP-driven all the cellular biochemical processes might be affected. Moreover, the alterations in the levels and activities of various parameters showed a linear trend in progression with time. This study has the uniqueness in the sense that it into account both dose- and time-dependent pattern of BPA in oxidative stress generation.

From the findings of the present study, it can be concluded that the incubation of mitochondria isolated from rat liver with BPA, caused oxidative stress-mediated damages in mitochondria in both dose- and time-dependent manners. This study is formulating an ex vivo model for studying xenobiotics-induced mitochondrial oxidative stress. The probable mechanism(s) of generation of oxidative stress in mitochondria by BPA has been elucidated in Fig. 7 .

\section{ACKNOWLEDGMENTS}

Financial grant from DST-PURSE Programme, Department of Physiology, University of Kalyani is gratefully acknowledged to carry out this study.

\section{CONFLICT OF INTEREST}

The authors declare that there are no conflicts of interest.

\section{AUTHORS' CONTRIBUTIONS}

MD: Designing of problem, experimental study, manuscript preparation.

GP: Designing of problem, manuscript correction.

\section{REFERENCES}

1. Pivnenko K, Pedersen GA, Eriksson E, Astrup TF. Bisphenol A and its structural analogues in household waste paper. Waste Manage 2015;44:39-47.

2. Chen Y, Shu L, Qiu Z, Lee DY, Settle SJ, Hee SQ. Exposure to the BPA substitute bisphenol S causes unique alterations of germline function. PLoS Genet 2016;12:e1006223-45.

3. Kaur K, Chauhan V, Gu F, Chauhan A. Bisphenol A induces oxidative stress and mitochondrial dysfunction in lymphoblasts from children with autism and unaffected siblings. Free Radic Biol Med 2014;76:25-33. 
4. Sarkar K, Tarafder P, Nath PP, Paul G. Bisphenol A inhibits duodenal movement in rat BY increasing acetylcholinesterase activity and decreasing availability of free $\mathrm{Ca}^{2+}$ in smooth muscle cells. Int J Pharm Bio Sci 2013;4:679-88.

5. Sarkar K, Tarafdar P, Paul G. Bisphenol A inhibits duodenal movement ex vivo of rat through nitric oxide-mediated soluble guanylyl cyclase and $\alpha$-adrenergic signaling pathways. J Appl Toxicol 2015;36:131-9.

6. Berger A, Ziv-Gal A, Cudiamat J, Wang W, Zhou C, Flaws JA. The effects of in utero bisphenol A exposure on the ovaries in multiple generations of mice. Reprod Toxicol 2016;60:39-52.

7. Kazemi S, Mousavi SN, Aghapour F, Rezaee B, Sadeghi F, Moghadamnia AA. Induction effect of bisphenol A on gene expression involving hepatic oxidative stress in rat. Oxid Med Cell Longev 2016;2016:1-5.

8. Moreno-Sánchez R, Rodríguez-Enríquez S, Marín-Hernández A, Saavedra E. Energy metabolism in tumor cells. FEBS J 2007;274:1393-418.

9. Santulli G, Xie W, Reiken SR, Marks AR. Mitochondrial calcium overload is a key determinant in heart failure. ProcNatl Acad Sci 2017;112:11389-94.

10. Lenaz G. Role of mitochondria in oxidative stress and ageing. Biochim Biophys Acta 1998;1366:53-67.

11. Hollensworth SB, Shen C, Sim JE, Spitz DR, Wilson GL, LeDoux SP. Glial cell type-specific responses to menadione-induced oxidative stress. Free Radic Biol Med 2000;28:1161-74.

12. Sas K, Robotka H, Toldi J, Vécsei L. Mitochondria, metabolic disturbances, oxidative stress and the kynurenine system, with focus on neurodegenerative disorders. J Neurol Sci 2007;257:221-39.

13. Andreazza AC, Shao L, Wang JF, Vécsei L. Mitochondrial complex I activity and oxidative damage to mitochondrial proteins in the prefrontal cortex of patients with bipolar disorder. Arch Gen Psychiatry 2010;67:360-8.

14. Dutta M, Ghosh D, Ghosh AK, Rudra S, Bose G, Dey M, et al. High fat diet aggravates arsenic induced oxidative stress in rat heart and liver. Food Chem Toxicol 2014;66:262-77

15. Fiddler RM. Collaborative study of modified AOAC method of analysis for nitrite in meat and meat products. JAOAC Int 1977;60:594-9.

16. Griess P. Bemerkungen $\mathrm{zu}$ der abhandlung der H.H. Weselsky und benedikt 'ueber einige azoverbindungen. Eur $\mathrm{J}$ Inorg Chem 1879;12:426-8.

17. Buege JA, Aust SG. Microsomal lipid peroxidation. Meth Enzymol 1978;52:302-10

18. Dutta M, Ghosh AK, Basu A, Bandyopadhyay D, Chattopadhyay A. Protective effect of aqueous bark extract of Terminalia arjuna against copper ascorbate induced oxidative stress in vitro in goat heart mitochondria. Int J Pharm Pharma Sci 2013;5:439-47.

19. Sedlak J, Lindsay RH. Estimation of total, protein-bound, and nonprotein sulfhydryl groups in tissue with ellman's reagent. Anal Biochem 1968;25:192-205.

20. Levine RL, Williams JA, Stadtman ER, Shacter E. Carbonyl assays for determination of oxidatively modified proteins. Meth Enzymol 1994;233:346-57.

21. Marklund S, Marklund G. Involvement of the superoxide anione radical in the auto-oxidation of pyragallol and a convenient assay for superoxide dismutase. Eur J Biochem 1974;47:469-74.

22. Krohne-Ehrich G, Schirmer RH, Untucht-Grau R. Glutathione reductase from human erythrocytes. Isolation of the enzyme and sequence analysis of the redox-active peptide. Eur J Biochem 1977;80:65-71.

23. Dutta M, Ghosh AK, Rangari V, Jain G, Khobragade SM, Chattopadhyay A, et al. Silymarin protects against copper-ascorbate induced injury to goat cardiac mitochondria in vitro: Involvement of antioxidant mechanism(s). Int J Pharm Pharm Sci 2014;6:422-9.

24. Paglia DE, Valentine WN. Studies on the quantitative and qualitative characterization of erythrocyte glutathione peroxidase. J Lab Clin Med 1967;70:158-69.

25. Dutta M, Ghosh AK, Mishra P, Jain G, Rangari V, Chattopadhyay A, et al. Protective effects of piperine against copperascorbate induced toxic injury to goat cardiac mitochondria in vitro. Food Funct 2014;5:2252-67.

26. Chretien D, Pourrier M, Bourgeron T, Séné M, Rötig A, Munnich A, et al. An improved spectrophotometric assay of pyruvate dehydrogenase in lactate dehydrogenase contaminated mitochondrial preparations from human skeletal muscles. Clin Chim Acta 1995;240:129-36.

27. Duncan MJ, Fraenkel DG. Alpha-ketoglutarate dehydrogenase mutant of Rhizobium meliloti. J Bacteriol 1979;137:415-9.

28. Veeger C, Der Vartanian DV, Zeylemaker WP. Succinate dehydrogenase. Meth Enzymol 1969;13:81-90.

29. Dutta M, Ghosh AK, Jain G, Rangari V, Chattopadhyay A, Das T, et al. Andrographolide, one of the major components of Andrographis paniculata protects against copper-ascorbate induced oxidative damages to goat cardiac mitochondria in-vitro. Int J Pharm Sci Rev Res 2014;28:237-47.

30. Lowry OH, Rosebrough NJ, Farr AL, Randall RJ. Protein measurement with the Folin phenol reagent. J Biol Chem 1951;193:265-75.

31. Chance B, Mela L, Harris EJ. Interaction of ion movements and local anesthetics in mitochondrial membranes. Fed Proc 1968;27:902-6.

32. Raha S, Robinson BH. Mitochondria, oxygen free radicals, disease and ageing. Trend Biochem Sci 2000;25:502-8.

33. Wanasundara PK, Shahidi F. Process induced changes in edible oils. Adv Exp Med Biol 1998;434:135-60.

34. Hassan ZK, Elobeid MA, Virk P, Omer SA, ElAmin M, Daghestani MH, et al. Bisphenol A induces hepatotoxicity through oxidative stress in rat model. Oxid Med Cell Longev 2012;2012:1-6.

35. Cross RK, Wilson KT. Nitric oxide in inflammatory bowel disease. Inflamm Bowel Dis 2003;9:179-89.

36. Szentivanyi M, Zou AP Jr., Maeda CY, Mattson DL, Cowley AW Jr. Increase in renal medullary nitric oxide synthase activity protects from norepinephrine-induced hypertension. Hypertension 2000;35:418-23.

37. Mylonas C, Kouretas D. Lipid peroxidation and tissue damage. In Vivo 1999;13:295-309.

38. Norris KM, Okie W, Kimb WK, Adhikari R, Yoo S, King S, et al. A high-fat diet differentially regulates glutathione phenotypes in the obesity-prone mouse strains DBA/2J, C57BL/6J, and AKR/J. Nutr Res 2016;36:1316-24.

39. Zaidan E, Sims NR. Reduced activity of the pyruvate dehydrogenase complex but not cytochrome c oxidase is associated with neuronal loss in the striatum following short-term forebrain ischemia. Brain Res 1997;772:23-8.

40. Jo SH, Son MK, Koh HJ, Lee SM, Song IH, Kim YO, et al. Control of mitochondrial redox balance and cellular defence against oxidative damage by mitochondrial $\mathrm{NADP}^{+}$-dependent isocitrate dehydrogenase. J Biol Chem 2001;276:16168-76.

41. Chitra KC, Latchoumycandane C, Mathur PP. Induction of oxidative stress by bisphenol $\mathrm{A}$ in the epididymal sperm of rats. Toxicology 2003;185:119-27.

42. Moon MK, Kim MJ, Jung IK, Koo YD, Ann HY, Lee KJ, et al. Bisphenol A impairs mitochondrial function in the liver at doses below the no observed adverse effect level. J Korean Med Sci 2012;27:644-52.

43. Kumari S, Sharma M, Singla SK. Potential protective effect of apocynin in ethylene glycol-induced hepatic damage by attenuation of mitochondrial oxidative stress. Asian J Pharm Clin Res 2016;9:154-8. 